\title{
The impact of agricultural drains on water quality and Phyto- zooplankton communities in fish farms, Egypt.
}

\author{
Abd El-Halim A. Saad ${ }^{1}$; Ahmed S. Abd El-Gawad ${ }^{2}$; Niema A. Ali ${ }^{2}$; \\ Nadia N. Bassuny ${ }^{3}$ \\ 1- Zoology Department, Faculty of Science, Ain Shams University, Egypt. \\ 2 - Central Lab for Aquaculture Research, Agricultural Research Center \\ 3- Labor University, Kafr El-Sheikh, Egypt.
}

\section{ABSTRACT}

This study was carried out on two fish farms in Kafr El-Sheikh and Sharkia governorates during 2011. The water supply sources of these farms were El-Gharbia and El-Wady drains respectively. The mean values of physico-chemical parameters of water in El-khashaa and Abbassa fish farms were: water temperature (24.66 and $\left.24.95^{\circ} \mathrm{C}\right) ; \mathrm{pH}$ (9.23 and 8.67); transparency (12.12 and $\left.15.24 \mathrm{~cm}\right)$; DO (5.36 and 6.3 $\mathrm{mg} / \mathrm{l}$ ); total alkalinity (330.9 and $340.3 \mathrm{mg} / \mathrm{l})$ and total hardness (689.5 and 260.0 $\mathrm{mg} / \mathrm{l})$, respectively. The major nutrient concentrations $(\mathrm{N} \& \mathrm{P})$ at the main feeder were much higher than the corresponding values at fish farms. Nitrogen concentrations analysis indicated the highest values of $\mathrm{NH}_{3}-\mathrm{N}$ over $\mathrm{NO}_{3}-\mathrm{N}$ in the selected fish ponds (1.94 and $1.22 \mathrm{mg} / \mathrm{l}$ respectively). Phytoplankton in the present study were represented by four groups; Chlorophyceae, Cyanophyceae, Bacillariophyceae and Euglenophyceae, where Chlorophyceae dominated other groups. Zooplankton were represented by four groups; Rotifera, Copepoda, Ostracoda and Cladocera. Rotifera and Cladocera were the dominant groups. Results indicated that the drainage water affects physical, chemical and biological characteristics of fish farms.

Keywords: El-Gharbia drain, El-Wady drain, phytoplankton, zooplankton, fish farms physical and chemical parameters.

\section{INTRODUCTION}

The agricultural drainage water is considered as one of the most important water sources for fish farms in Egypt, due to shortage of water. On the other hand, its water contains fertilizers, pesticides and effluents of industrial activities, in addition to sewage effluents, supplying the water bodies and sediment with huge quantities of inorganic anions and heavy metals (Saeed \& Mohammed, 2012). Changes in the chemical composition of the water are followed by significant changes in structure of their biota. Therefore, the quality of water should be assessed in the basis of physical, chemical and biological characteristics in order to provide a complete spectrum of information for proper water (Marneff et al., 1996).

Phytoplankton community is common inhabitant of surface water and is beneficial to the health of a water body. They represent primary producers of organic matter which provide food base for most marine and freshwater food chains and play an important role in the equilibrium of aquatic ecosystem (Field et al., 2007). Phytoplankton responds rapidly and predictably to a wide range of pollutants (Wong \& Dixon, 1995 ).

On the other hand, zooplankton community is an important grazer and nutrient regeneration of phytoplankton (Carney \& El-Ser, 1990). Zooplankton is a good indicator of changes in water quality, because it is strongly affected by environmental 
condition and responds quickly to change in environmental quality (Gannon \& Stemberger, 1978). The study of the distribution of zooplankton is useful for the general monitoring of certain aspects of the environment, such as eutrophication, pollution, warning trend and long-term changes, which are signs of environmental disturbance (El-Shabrawy, 2002).

The present study aimed to investigate the physical, chemical and biological characteristics of agricultural drainage water used in fish farms and its effect on plankton communities .

\section{MATERIALS AND METHODS}

\section{Study area:}

This study was carried out at two different fish farms:-

a) Al-khashaa; governmental fish farm that is managed by General Authority For Fish Resources Development (GAFRD), Elhamoul, Kafr El-Shiekh governorate, which is provided by water through El-Gharbia main drain (Ketshenar). It extends from El- Gharbia governorate in the south to Kafr El-Sheikh governorate in the north. It receives drainage water from adjacent fields i.e. drainage system of the irrigation, industrial and sewage.

b) Central Laboratory for Aquaculture Research (CLAR), Abbassa, AbouHammad, Sharkeia governorate, the production fish farm that is provided by water through El-Wady drain, which receives agricultural wastes from surrounding lands. Each farm was stocked with Nile tilapia (Oreochromis niloticus) (monoculture system).

\section{Sampling:}

The samples of water, phytoplankton and zooplankton were collected monthly during the periol from June to December 2011 from:-

farm

1) Inlet [water sources El-Gharbia drain (D1) and El-Wady drain (D2)] of each

2) Water of three earthen ponds of each fish farm [ Al-khashaa ponds( P1) and Abbassa ponds (P2)] .

3) Outlet from El-khashaa fish farm (O1) and from Abbassa fish farm ( O2).

Physical and chemical parameters: Water temperature $(\mathrm{T})$ and dissolved oxygen (DO) were measured by oxygen meter (Model YSI 55) with oxygen and temperature probe. Transparency was determined by Secchi disc. Hydrogen ion concentration $(\mathrm{pH})$ was detected using $\mathrm{pH}$ meter (Model 301). Total alkalinity and total hardness were determined by titration method according to APHA (2000). Nitrate was detected by phenoldisulphonic acid method, then by using spectrophotometer (model, WPA Linton Cambridge UK) at wave length of $410 \mathrm{~nm}$, as described by (APHA, 2000), Un-ionized ammonia was determined by measureing ammonium concentration by Hach comparison apparatus following the method reported by APHA (2000) and orthophosphate was measured by ascorbic acid method according to APHA (2000) by using spectrophotometer (model, WPA Linton Cambridge UK).

Phytoplankton: one litter of water was collected from each selected sites, immediately preserved with Lugol's Iodine solution. In the laboratory, the samples are transferred into a glass cylinder and left five days for settling the supernatant siphoned off with plastic tube ended with plankton net $10 \mathrm{~mm}$ mesh diameter. Each sample was examined and counted according to APHA (2000).Different species were identified according to Prescott (1978). 
Zooplankton samples were collected from the selected sites by filtering 30 liters from surface water through a zooplankton net of $55 \mu \mathrm{m}$ mesh diameter. Collected samples were kept in plastic bottles with some water and 4\% formalin was added as a preservative(APHA, 2000). Samples were studied under the compound microscope and specimens were identified. Zooplankton numbers were expressed as number of organisms per litter. The main taxonomic reference used for identification of zooplankton was Pennak (1953).

\section{Statistical analysis}

The variation in the water variables in relation to different, sites and biotic factors were assessed using one way analysis of the variance (ANOVA). These techniques were used according to SAS software (SAS 1988, SPSS 1999).

\section{RESULTS AND DISCUSSION}

Water temperature: The surface water temperature ranged between $13.7-33.115^{\circ} \mathrm{C}$ and $15.8-33.67{ }^{\circ} \mathrm{C}$ in Al-Khashaa and Abbassa fish farms, respectively. The variations in temperature were mainly due to different the location of sites.Water temperature was higher at ponds $\left(\mathrm{P} 1,24.96^{\circ} \mathrm{C}\right.$ and $\left.\mathrm{P} 2,25.7^{\circ} \mathrm{C}\right)$ (Table1) than drains, this attributed to the shallowness of most tropical fish ponds. These results were in accordance with Ali ( 2007).

Hydrogen ion concentration (pH): The values of $\mathrm{pH}$ lie on the alkaline side at all sites, with total mean of 9.23 and 8.67 in Al-Khashaa and Abbassa farms, respectively. On the other hand, there was a highly significant spatial variation in $\mathrm{pH}$ measurements $(\mathrm{p}<0.001)$. The increase of $\mathrm{pH}$ values may be due to increase of photosynthesis activity by phytoplankton. The $\mathrm{pH}$ recorded at drains (D1,8.99andD2 8.42) relatively low as compared with fish ponds (Table1). This result may be attributed to the wide variation of phytoplankton between feeder/ drains and fish ponds. Where $\mathrm{pH}$ changes in surface water result from the interaction of various biotic and a biotic processes (Konsowa, 2007).

Transparency: The highest readings of the Secchi disc were observed in drains with mean values of 18.27 and $23.71 \mathrm{~cm}$, while the minimum transparency values were found in ponds with mean values of 8.27 and $8.11 \mathrm{~cm}$, at Al-Khashaa and Abbassa farms respectively. Transparency at ponds was lower than drains, this may be due to low depth, feeding, concentration of chlorophyll and soil particles in ponds. The results are agree with the study of Osman et al. (2010). There was a significant variation in transparency measurement $(\mathrm{p}<0.001)$ (Table1).

Dissolved Oxygen values varied during the study period, with mean values 5.36 and $6.3 \mathrm{mg} / \mathrm{l}$ at Al- Khashaa and Abbassa fish farms, respectively. There was significant spatial variation in DO concentration $(p>0.001)$ (Table 1). The low values of DO were at drains (D1, 3.75 and D2, 5.87mg/l); this may be due to the presence of organic matter loaded by the higher amounts of drainage water discharged in these areas, but the high values were recorded at ponds, attributed to the abundance of phytoplankton communities.

Total alkalinity: The highest values were observed in ponds, while the lowest values were found at drains with mean values of 304.6 and $280.0 \mathrm{mg} / \mathrm{l}$, in Al-Khashaa and Abbassa fish farms respectively (Table1). There was a significant spatial variation in total alkalinity measurement $(\mathrm{P}<0.001)$. The highest values were recorded at ponds, which may be attributed to feeding and organic fertilization in them. That is because bacteria generated $\mathrm{Co}_{2}$ from feed metabolism and manure decomposition dissolved calcium and magnesium carbonate present in the pond sediments (Boyd, 1990). The 
results were in accordance with the study of Ezzat et al. (2012), who reported that the range of total alkalinity values were 282.5 to $426.5 \mathrm{mg} / \mathrm{l}$ in drains water.

Table 1: Spatial variations (means+2S) of some parameters of water in Al- khashaa and Abbassa fish

\begin{tabular}{|c|c|c|c|c|c|c|c|c|c|}
\hline \multirow[b]{2}{*}{ Parameters } & \multicolumn{4}{|c|}{ Al- Khashaa fish farm } & \multicolumn{4}{|c|}{ Abbassa fish farm } & \multirow[t]{2}{*}{ F value } \\
\hline & $\mathbf{D}_{1}$ & $\mathbf{P}_{1}$ & $\mathbf{O}_{1}$ & $\begin{array}{l}\text { Total } \\
\text { mean }\end{array}$ & $\mathbf{D}_{2}$ & $\mathbf{P}_{2}$ & $\mathbf{O}_{2}$ & $\begin{array}{l}\text { Total } \\
\text { mean }\end{array}$ & \\
\hline \multirow{2}{*}{$\mathbf{T}\left({ }^{\circ} \mathrm{C}\right)$} & 24.4 & 24.96 & 24.61 & 24.66 & 23.62 & 25.7 & 25.5 & 24.95 & \multirow{2}{*}{0.325} \\
\hline & \pm 6.6 & \pm 7.3 & \pm 6.9 & +6.82 & +4.9 & \pm 6.15 & +4.7 & +5.3 & \\
\hline \multirow{2}{*}{ pH } & 8.99 & 9.45 & 9.26 & 9.23 & $\overline{8} .42$ & 9.11 & $\overline{8.47}$ & $\overline{8} .67$ & \multirow{2}{*}{$8.08^{* * *}$} \\
\hline & +0.49 & +0.27 & \pm 0.37 & \pm 0.43 & +0.83 & \pm 0.96 & +0.83 & +0.92 & \\
\hline \multirow{2}{*}{ Tran. (cm) } & 18.27 & 8.27 & 9.52 & 12.12 & 23.71 & 8.11 & 13.89 & 15.24 & \multirow{2}{*}{$26.9^{* * *}$} \\
\hline & \pm 8.86 & +2.37 & +2.93 & \pm 7.02 & +8.23 & +2.7 & +4.01 & +8.5 & \\
\hline \multirow{2}{*}{ DO (mg/l) } & 3.75 & 6.23 & 6.09 & 5.36 & 5.87 & 8.11 & 4.92 & 6.3 & \multirow{2}{*}{$15.4^{* * *}$} \\
\hline & \pm 1.5 & \pm 1.91 & +2.01 & +2.12 & +1.95 & \pm 1.1 & \pm 1.55 & +2.05 & \\
\hline \multirow{2}{*}{$\begin{array}{l}\text { T. alk } \\
\text { (mg/l) }\end{array}$} & 304.6 & 340.1 & 348.0 & 330.9 & 280.0 & $\overline{403.8}$ & 337.1 & 340.3 & \multirow{2}{*}{$13.3^{* * *}$} \\
\hline & +19.5 & \pm 82.5 & \pm 61.8 & \pm 62.5 & +51.8 & \pm 43.7 & \pm 34.9 & \pm 66.9 & \\
\hline \multirow{2}{*}{$\begin{array}{c}\text { T. H } \\
(\mathrm{mg} / \mathrm{l})\end{array}$} & $\overline{6} 60.0$ & $\overline{6} 25.7$ & $\overline{782.9}$ & $\overline{689.5}$ & 306.9 & 280.7 & 192.6 & 260.0 & \multirow{2}{*}{$32.6^{* * *}$} \\
\hline & +300.6 & \pm 195.6 & +284.9 & +268.9 & +88.1 & +94.6 & +57.7 & +94.3 & \\
\hline \multirow{2}{*}{$\begin{array}{c}\mathrm{No}_{3} \\
(\mathrm{mg} / \mathrm{l})\end{array}$} & 3.26 & 1.85 & 1.42 & 2.18 & 2.3 & 1.31 & 0.84 & 1.48 & \multirow{2}{*}{$17.6^{* * *}$} \\
\hline & +1.06 & +0.40 & \pm 0.39 & +1.05 & \pm 1.8 & \pm 0.7 & \pm 0.4 & +1.27 & \\
\hline \multirow{2}{*}{$\begin{array}{c}\mathrm{NH}_{3} \\
(\mathrm{mg} / \mathrm{l})\end{array}$} & 1.61 & 1.94 & 1.89 & 1.812 & 0.739 & 1.22 & 0.753 & 0.904 & \multirow{2}{*}{1.406} \\
\hline & +2.36 & +2.06 & +3.1 & \pm 2.7 & +0.74 & +1.3 & +0.75 & +0.97 & \\
\hline \multirow{2}{*}{$\begin{array}{c}\text { O.P } \\
(\mathrm{mg} / \mathrm{l})\end{array}$} & 0.96 & 0.638 & 0.647 & 0.747 & 0.85 & 0.54 & 0.418 & 0.601 & \multirow{2}{*}{$6.57^{* * *}$} \\
\hline & \pm 0.34 & \pm 0.43 & \pm 0.3 & \pm 0.38 & \pm 0.42 & +0.38 & \pm 0.24 & \pm 0.4 & \\
\hline
\end{tabular}

Total Hardness: There was a significant variation in T.H. concentrations $(\mathrm{P}<0.001)$. The maximum values were recorded at drains and the minimum were at ponds with mean values of 689.5 and $280.0 \mathrm{mg} / \mathrm{l}$ at Al- Khashaa and Abbassa farms respectively (Table1). The increasing total hardness value at drains may be due to higher levels of nutrients in water, and the increasing of salinity led to increase of hardness, especially in Al-Khashaa fish farm, which is near to Burullus lake. This result agrees with that observed by Adham (2001).

Nitrate: Its concentrations decreased in ponds and increased in drains (D1 and D2) with mean values of 3.26 and $2.3 \mathrm{mg} / \mathrm{l}$ (Table 1). This may be related to different sewage effluents that contain nitrate, which originated from domestic and agricultural wastes, especially from N-containing fertilizers. Similar observation was recorded in fish ponds and El- Berka drain in Fayoum by Konsowa (2007).

Ammonia values were observed in drains lower (mean values 1.61 and $0.739 \mathrm{mg} / \mathrm{l}$ ) than ponds and its outlet. This may be attributed to high stock of fish, excretion of fish and decomposition of excess un-consumed feed represented another ammonia sources in ponds, moreover to higher $\mathrm{pH}$ at them, while at higher $\mathrm{pH}$, more and toxic ammonia is released to critical levels (Boyd, 1990). Also, this study agrees with Meade (1985) and Konsowa (2007) who reported that ammonia concentration was correlated with the amount of stocked fish population and supplementary food added to the fish ponds (Table 1).

Orthophosphate: There was a significant variations in orthophosphate values $(\mathrm{P}<0.001)$. The lowest value of phosphate concentration was recorded in ponds and the highest was in drains (D1 and D2), with mean values of 0.96 and $0.85 \mathrm{mg} / \mathrm{l}$ respectively. This may be due to agricultural run-off containing phosphate fertilizers as well as wastewater (domestic) containing detergents. The values of phosphate were similar with the study of Ali (2007) in fish ponds . 


\section{Biological studies}

Phytoplankton community was represented by four groups; Chlorophyceae, Cyanophyceae, Bacillariophyceae and Euglenophyceae. The total standing crop of phytoplankton decreased in July and August with mean values of $64.27 \times 10^{3}$ and $83.844 \times 10^{3} \mathrm{org} / 1$ respectively, and regained its maximum abundance during September and October with mean values of $130.76 \times 10^{3}$ and $196.71 \times 10^{3} \mathrm{org} / \mathrm{l}$ at Al-khashaa and Abbassa fish farms respectively (Table2). This may be due to stagnation of water, high ammonia concentration and high nutrients salts. The decrease values during July and August may be attributed to the efficient grazing by zooplankton and fish. This coincided with results of Ali (2007) who reported that phytoplankton considered the main food of tilapia species especially at early stages. The highest density of the ponds water (mean P1, $108.4 \times 10^{3}$ and P2, 219.224 x $10^{3}$ org /1 ) (Table 2), with phytoplankton than drains was related to the increase of ammonia concentration as a result of the fish farming activities. These ammonia levels could be absorbed by the available phytoplankton, which subsequently converts the nitrogenous compounds into amino acids that depict a much idealized algal cell as pointed out by Vymazan (1995). The highly available nutrients in fish ponds led to subsequent increase in phytoplankton production (Hargreaves, 1998).

Table 2: Standing crop of total phytoplankton (org/1 x $\left.10^{3}\right)$ in water samples collected from Al- Khashaa

\begin{tabular}{|c|c|c|c|c|c|c|c|c|c|}
\hline \multicolumn{2}{|c|}{ Sites Months } & June & July & Aug. & Sept. & Oct. & Nov. & Dec. & Mean \\
\hline \multirow{4}{*}{ 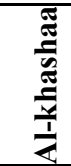 } & $\mathrm{D}_{1}$ & 74.73 & 36.995 & 75.95 & 75.46 & 84.08 & 60.27 & 57.82 & 66.47 \\
\hline & $\mathbf{P}_{1}$ & 93.1 & 100.94 & 81.83 & 134.51 & 168.07 & 72.28 & 108.05 & 108.4 \\
\hline & $\mathrm{O}_{1}$ & 109.76 & 45.88 & 138.18 & 100.94 & 140.14 & 73.99 & 51.45 & 95.62 \\
\hline & Mean & 92.53 & 64.27 & 98.65 & 103.64 & 130.76 & 68.85 & 72.44 & 90.163 \\
\hline \multirow{4}{*}{ 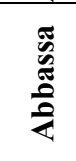 } & $\mathbf{D}_{2}$ & 128.625 & 119.315 & 67.62 & 94.08 & 90.65 & 79.38 & 77.42 & 93.87 \\
\hline & $\mathbf{P}_{2}$ & 236.83 & 193.773 & 162.843 & 312.293 & 268.68 & 177.87 & 182.28 & 219.224 \\
\hline & $\mathrm{O}_{2}$ & 98.98 & 103.39 & 21.07 & 183.75 & 40.18 & 220.5 & 34.3 & 100.31 \\
\hline & Mean & 154.81 & 138.81 & 83.844 & 196.71 & 133.171 & 159.25 & 98 & 137.8 \\
\hline
\end{tabular}

Chlorophyceac (green algae) dominated other groups of phytoplankton, forming $40.14 \%$ and $29.8 \%$ of total phytoplankton (Table 3), with mean of $108.57 \times 10^{3}$ and $122.99 \times 10^{3} \mathrm{org} / 1$ in Al-khashaa and Abbassa fish farms, respectively (Tables 4\&5). Abdalla et al. (1991) concluded that the increase of green algae appears to be related to the increase of pollution. The most characteristic features of eutrophication are the change of algal flora from diatom assemblage to green and blue algae which are usually favored by increased dissolved organic load (Moussa, 2004). The high abundance of green algae in ponds may be due to Nile tilapia could not consume it completely even they are phytophagous fishes. The second common phytoplankton groups in Al-khashaa and Abbassa farms were Bacillariophyceae and Cyanophyceae, which constituted $36.52 \%\left(691.443 \times 10^{3} \mathrm{org} / \mathrm{l}\right)$ and $25.0 \%\left(722.913 \times 10^{3} \mathrm{org} / \mathrm{l}\right)$ of total phytoplankton, respectively (Table 3 ). The increasing of diatoms may be attributed to burning of rice straw which contains silica and discharging it into drain, where the silica is considered the limited growth factor for diatoms. This result agrees with that observed by Chakraverty \& Kaleemullah (1991), but increasing of Cyanophyceae was related to low nitrogen and high $\mathrm{pH}$ (Smith, 1983). Phytoplankton composition changes in the course of time and sites, are adapting to changes in the trophic state of the water body, in addition to numerous factors that affecting phytoplankton abundance including nutrients availability (Stocknar \& Shortreed, 1988). 
Table 3: Standing crop of different phytoplankton (org/l $\times 10^{3}$ ) and their percentage frequency to total phytoplankton in Al-Khashaa and Abbassa fish farms.

\begin{tabular}{|c|c|c|c|c|}
\hline \multirow{2}{*}{ Groups } & \multicolumn{2}{|c|}{ Al-Khashaa farm } & \multicolumn{2}{|c|}{ Abbassa farm } \\
\hline & $\mathrm{No} / \mathrm{l} \times 10^{3}$ & $\%$ & $\mathrm{No} / \mathrm{l} \times 10^{3}$ & $\%$ \\
\hline Green & 759.99 & 40.14 & 860.93 & 29.8 \\
\hline Blue & 150.43 & 7.94 & 722.913 & 25.0 \\
\hline Diatoms & 691.443 & 36.52 & 673.483 & 23.2 \\
\hline Euglena & 291.55 & 15.4 & 636.51 & 22.0 \\
\hline Total & 1893.413 & 100 & 2893.837 & 100 \\
\hline
\end{tabular}

Table 4: Monthly variations of phytoplankton groups (org/1 x 10 $0^{3}$ in water samples collected from Al- Khashaa fish farm.

\begin{tabular}{|c|c|c|c|c|c|c|c|c|}
$\begin{array}{c}\text { Months } \\
\text { Groups }\end{array}$ & June & July & Aug. & Sept. & Oct. & Nov. & Dec. & Mean \\
\hline Green & 81.585 & 49.98 & 80.115 & 200.655 & 194.04 & 107.31 & 46.305 & 108.57 \\
\hline Blue & 21.81 & 13.475 & 17.15 & 28.665 & 27.685 & 22.54 & 19.11 & 21.491 \\
\hline Diat. & 124.46 & 102.66 & 154.8 & 63.95 & 120.78 & 27.69 & 97.103 & 98.78 \\
\hline Eug. & 42.875 & 40.425 & 43.855 & 24.5 & 49.98 & 35.28 & 54.635 & 41.65 \\
\hline Mean & 67.7 & 51.635 & 73.98 & 79.44 & 98.12 & 48.2 & 54.29 & 67.62 \\
\hline
\end{tabular}

Table 5:Monthly variations of phytoplankton groups (org/l x $\left.10^{3}\right)$ in water samples collected from Abbassa fish farm.

\begin{tabular}{|c|c|c|c|c|c|c|c|c|}
\hline $\begin{array}{c}\text { Months } \\
\text { Groups }\end{array}$ & June & July & Aug. & Sept. & Oct. & Nov. & Dec. & Mean \\
\hline Green & 137.608 & 126.42 & 84.362 & 142.672 & 146.347 & 166.028 & 57.493 & 122.99 \\
\hline Blue & 84.28 & 68.355 & 67.538 & 192.325 & 89.343 & 107.637 & 113.435 & 103.27 \\
\hline Diat. & 146.57 & 151.9 & 59.372 & 113.108 & 84.933 & 80.523 & 37.077 & 96.21 \\
\hline Eug. & 90.65 & 75.133 & 40.262 & 85.995 & 78.89 & 123.562 & 142.018 & 90.93 \\
\hline Mean & 114.78 & 105.45 & 62.88 & 133.52 & 99.88 & 119.44 & 87.51 & 103.35 \\
\hline
\end{tabular}

Zooplankton was represented by four groups; Rotifera, Copepoda, Ostracoda and Cladocera, forming $88.04 \%, 8.95 \%, 1.93 \%$ and $1.08 \%$, also $16.53 \%, 20.15 \%, 9.03 \%$, and $54.3 \%$ respectively, with total mean of 101.1 and $68.6 \mathrm{org} / \mathrm{l}$ at Al-khashaa and Abbassa fish farms respectively (Tables $6 \& 7$ ). The highest number of zooplankton organisms may be due to increase nutrients and organic matter as well as phytoplankton organisms. The total standing crop of zooplankton increased in fish ponds with mean values of 117 and $125.7 \mathrm{org} / \mathrm{l}$, and decreased in drains with mean values of 85.3 and 47.4 at Al- khashaa and Abbassa fish farms respectively (Table 6). Increasing densities in ponds may be attributed to high density of phytoplankton. This complied with Vasconcelos (1994), who concluded that the phytoplankton availability was considered the main reason for fluctuation of zooplankton density, although temperature and dissolved oxygen interference may also have played a role. But the low number of zooplankton in drains may be related to the decrease in nutrients concentration, where it covered with macrophytes and hence depriving the water from its nutrient and suppressing the phytoplankton growth and decreasing zooplankton. Similar observation was recorded by Ibrahim et al. (1997). Rotifera was the most abundant group in all months and sites in Al- khashaa fish farm. It comprised more than $88 \%$ with mean values of 267.1 org/l (Table 8), where increased in August and decreased in November, this may be attributed to restrict by low temperature. While the increasing during August may be related to increase of organic matter. The dominance of rotifers over the other groups indicated that a highly eutrophic ecosystem and shown slight signs of partial organic pollution, so it was classified 
as bioindicator of water quality (El-Shabrawy, 2002). This indicates that Al-khashaa fish farms was a highly eutrophic and suffered from slight sign of pollutants. These results agreed with the studies of Ali (2007) and Tawfiek (2011), who reported that dominance of Rotifera in fish ponds.

Table 6: Standing crop of total zooplankton (org/1) in water samples collected from Al- Khashaa and Abbassa fish farms during different months.

\begin{tabular}{|c|c|c|c|c|c|c|c|c|c|}
\hline \multicolumn{2}{|c|}{ Months } & June & July & Aug. & Sept. & Oct. & Nov. & Dec. & Mean \\
\hline \multirow{4}{*}{ 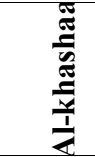 } & $\mathbf{D}_{1}$ & 167 & 79 & 145 & 90 & 39 & 39 & 38 & 85.3 \\
\hline & $\mathbf{P}_{1}$ & 163 & 75 & 249 & 96 & 85 & 43 & 108 & 117 \\
\hline & $\mathrm{O}_{1}$ & 115 & 60 & 227 & 113 & 70 & 43 & 80 & 101 \\
\hline & Mean & 148.3 & 71.35 & 207 & 99.7 & 64.7 & 41.7 & 75.3 & 101.1 \\
\hline \multirow{4}{*}{ 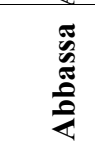 } & $\mathbf{D}_{2}$ & 87 & 12 & 13 & 11 & 65 & 75 & 67 & 47.14 \\
\hline & $\mathbf{P}_{2}$ & 97 & 33 & 29 & 62 & 171 & 226 & 263 & 125.7 \\
\hline & $\mathbf{O}_{2}$ & 35 & 5 & 15 & 53 & 65 & 35 & 20 & 33 \\
\hline & Mean & 73 & 17 & 19 & 42 & 100.3 & 112 & 116.7 & 68.6 \\
\hline
\end{tabular}

Table 7: Standing crop of different zooplankton groups (org/l) and their percentage frequency to total zooplankton in Al- khashaa and Abbassa fish farms.

\begin{tabular}{|c|c|c|c|c|}
\hline \multirow{2}{*}{ Groups } & \multicolumn{2}{|c|}{ Al-Khashaa farm } & \multicolumn{2}{c|}{ Abbassa farm } \\
\cline { 2 - 5 } & No/l & \% & No/l & \% \\
\hline Rotifera & 1870 & 88.04 & 238 & 16.53 \\
\hline Copepoda & 190 & 8.95 & 290 & 20.15 \\
\hline Ostracoda & 41 & 1.93 & 130 & 9.03 \\
\hline Cladocera & 23 & 1.08 & 781 & 54.3 \\
\hline Total & 2124 & 100 & 1439 & 100 \\
\hline
\end{tabular}

Table 8: Monthly variations of zooplankton groups (org/l) in water samples collected from Al- Khashaa fish farm.

\begin{tabular}{|c|c|c|c|c|c|c|c|c|}
\hline $\begin{array}{c}\text { Months } \\
\text { Groups }\end{array}$ & June & July & Aug. & Sept. & Oct. & Nov. & Dec. & Mean \\
\hline Rot. & 420 & 203 & 590 & 256 & 157 & 108 & 136 & 267.1 \\
\hline Cope. & 25 & 11 & 27 & 12 & 12 & 16 & 87 & 27.14 \\
\hline Ostr. & 0.0 & 0.0 & 5 & 21 & 15 & 0.0 & 0.0 & 6 \\
\hline Clad. & 0.0 & 0.0 & 0.0 & 10 & 10 & 0.0 & 3 & 3.3 \\
\hline Mean & 111 & 53.5 & 155.5 & 74.8 & 48.5 & 31 & 56.5 & 75.9 \\
\hline
\end{tabular}

Cladocera dominated other groups of zooplankton forming $54.3 \%$ with mean of $111.6 \mathrm{org} / \mathrm{l}$ in Abbassa farm (Table 9), where they increased during December and decreased during July, this may be due to predation by plankophagous fish, or fish predation on large zooplankton (Cladocera and Copepoda) (Pourriot et al., 1997). The increase of Cladocera during December was due to increase of nutrients and dissolved oxygen in this month.This coincided with results of Salem (2006) who reported that Cladocera had a positive correlation between DO and low level of pollutant, but Rotifera had a negative relation, so Cladocera has been used as an indicator of water quality. The results agreed with the studies of Moussa (2004) and Ali (2007) who pointed out that Cladocera dominance in brackish water and fish ponds. Copepoda was the second common zooplankton groups in Al-Khashaa and Abbassa fish farms. while Ostracoda showed relatively slight occurrence as compared with the total number of zooplankton. There are many environmental factors, which considered important in setting zooplankton distribution patterns, such as chlorophyll "a" content ,biomass of fish, light intensity, temperature, dissolved oxygen concentration (Huntly, 1986 \& Lauridsen et al., 1999) and turbulence (Kiorboe \& Saiz, 1995). Also 
Premazzi and Chiaudani (1992) showed that eutrophication effects zooplankton composition, shifting the dominance from large species (Cladocera, Copepoda) to small species (Rotifera).

Table 9: Monthly variations of zooplankton groups (org/l) in water samples collected from Abbassa fish farm.

\begin{tabular}{|c|c|c|c|c|c|c|c|c|}
\hline $\begin{array}{c}\text { Months } \\
\text { Groups }\end{array}$ & June & July & Aug. & Sept. & Oct. & Nov. & Dec. & Mean \\
\hline Rot. & 90 & 30 & 3 & 17 & 17 & 56 & 25 & 34 \\
\hline Cope. & 21 & 13 & 6 & 49 & 56 & 59 & 86 & 41.4 \\
\hline Ostr. & 3 & 0 & 40 & 5 & 55 & 18 & 9 & 18.6 \\
\hline Clad. & 105 & 6 & 8 & 55 & 173 & 203 & 231 & 111.6 \\
\hline Mean & 55 & 12 & 14 & 31.5 & 75 & 84 & 88 & 51.4 \\
\hline
\end{tabular}

\section{CONCLUSION}

The obtained results declared that, the agricultural drainage water has adverse effects on the quality of water and plankton communities in fish farms where AlKhashaa farm was more eutrophic than Abbassa farm, due to El-Gharbia main drain that was more polluted than El-Wady drain.

\section{REFERENCES}

Abdalla, A.A.F.; Mcnabb, C.D. and Batterson, T.R. (1991): Ammonia dynamics in fertilized fish ponds stocked with Nile tilapia. Progressive Fish- Culturist, 58: 117-123.

Adham, K. G. (2001): Metallic micro pollutants in the harvest of Oreochromins niloticus (Linnaeus, 1757) from polluted waters: wild life and human concerns. Pakistan J. Bio., Sci.,4 (12): 1550-1558.

Ali, N., A. (2007): Ecological Study on Some Water Characteristics Used in Fish Farms and Their Relations to Fish Productivity. Ph.D. Thesis, Fac. Sci., AlAzhar univ.

Ali, M.M. (2007): An analysis of the impact of human activities on water quality and ecological responses in the Suez irrigation Canal. Management of Environmental Quality. An international Journal, 15(3): 377-401.

American Public Health Association (APHA) (2000): Standard methods for the examination of water and waste water $16^{\text {th }}$ ed., Washington, D.C

Boyd, C.E. (1990): Water quality in ponds for aquaculture. Alabama Agricultural[,Experiment Station, Auburn University, Alabama USA..

Carney, H.J. and El-Ser, J.J. (1990): Strength of zooplankton-phytoplankton coupling in relation to lake trophic state large lakes: Ecological structure and function (Eds.M.M.Tizler \& C.serruya), Springer Verlag, New York. pp. 615-631.

Charkraverty, A. and Kaleemullah , S. (1991): Production of morphous Silica and combustible gas from rice straw. J. Materials Sci., 26: 4554-4560.

El-Shabrawy, G. M. (2002): Ecological survey of Burullus nature protectorate (zooplankton). EEAA, Med Wet Coast, Egypt, pp. 31.

Ezzat, S.M.; Mahdy, H.M.; Abo-State, M.A.; Abd El-Shakour, E.H. and EBahnasauiy., M.A. (2012): Water quality assessment of River Nile at Rosetta bransh:Impact of drains discharge. Middle- East Journal of Scientific Research, 12 (4): 413-423.

Field, C.B.; Behrenfeld, M.J.; Randerson. J.T. and Fallkowski, P. (2007): Primary production of the biosphere: Integrating terrestrial and oceanic components. 
Science, 281: 237-240.

Gannon, J.E and Stemberger, R.S (1978): Zooplankton especially Rotifer and crustacean as indicator of water quality. Trans. Am. Micros . Soc. 971: 16-35.

Hargreaves, J.A. (1998): Nitrogen biogeochemistry of aquaculture ponds. Aquaculture, 166: 181-212.

Huntley, M. (1986): Experimental approaches to the study of vertical migration of zooplankton. Contribution of marine Sci. suppleme., 27: 2107-2114.

Ibrahim, M.A.; Moussa, A. A and El- Bokhty, A.E (1997): Environmental factors affecting abundance and distribution of macrobenthic organisms in lake Manzala, Egypt. Bull. Inst. Oceanogr \& fish., (23): 315-331.

Kiorboe, T. and Saiz, E. (1995): Plankivorous feeding in calm and turbulent environments, with emphasis on Copepods. Mar. Ecol. Prog. Ser., 122: 135145.

Konsowa, A.H (2007): Ecological studies on fish farms of El-Fayoum depression. E. J. Aquat. Res., 33 (1): 290-299.

Lauridsen, T. L., Joppesen, E.; Mitchell, S.F.; lodge, D.M. and Burks, R.L (1999): Horizontal distribution of zooplankton in lakes with contrasting fish densities and nutrient levels. Hydrobiologia, 408/409: 241-250.

Marneffe, Y.; Comblin, S.; Bussers, J. and Thome, J. (1996): Biomonitoring of the water quality in the River Warche (Belgium): Impact of tributaries and sewage effluent. Netherlands, Zoo., 46 (3-4): 337-350.

Meade, J. W. (1985): Allowable ammonia for fish culture. Prog. Fish- Cult., 47: 135145.

Moussa, S.M. (2004): Impact of Inorganic Pollutants on Aquatic Environment and fish Performance in Lake Burullus. Ph. D. Thesis, Ins. Env. Stud. \& Res., Ain shams Univ.

Osman, M.A.; Mohamed, M.A.M.; Ali, M.H.H and Al-Afify, A.D.G. (2010): Assessment of agriculture drainage water quality to be used for fish farm irrigation. Natu. and Sci. J., 8 (8): 60-74.

Pennak, R.W. (1953): Freshwater invertebrates of the United States. The Ronald press Co., New York, New York.

Pourriot, R.; Rougier, C. and Anne, M. (1997): Origion and development of river zooplankton: Example of the marine. Hydrobio., 345: 143-148.

Premazzi, G. and Chiaudani, G. (1992): Current approach to assess water quality in Lake .In River water quality. Published by the Commission of the European Comm.. pp.249-303.

Prescott, G.W. (1978): How to know the freshwater algae. WMC Brown Co., publishers, Iowa, USA.

Saeed, S.M and Mohammed, M.A. (2012): Influence of physico-chemical characteristics of water on metals accumulation in water and Tilapia zilli. inhabiting different habitats in Egypt. Journal of the Arabia Aquaculture Society, 7 (1): 29-50.

Salem, T.A.A. (2006): Impact of Water Quality on the Biodiversity Among Certain Sectors of the River Nile, Egypt. Ph. D. Thesis, Inst. Env. Stud. \& Res., Ain Shams Univ.

Smith, V.H. (1983):Low nitrogen to phosphorus ratios favor dominance by blue-green algae in lake. Phtop.Sci (washington.Dc),221:669-671.

Stockner, J. G and Shortreed, K.S. (1988): Responses of Anabeana and Synechococcus to manipulation of nitrogen: phosphorus ratios in a lake fertilization experiment. Limnol. Oceanogr., 23: 112-119. 
Tawfiek, M.N.M. (2011): Effect of Polycuture of Different Stocking Ratios of Nile Tilapia and Carp Fish Reared in Earthen Pond on Growth Performance and Water Ecosystem. M.Sc. Thesis, Ins. Env. Stud \& Res., Ain Shams Univ.

Vasconcelos, V.M. (1994): Seasonal fluctuation of planktonic rotifers in Azibo reservoir (Portugal) .Hydrobio., 294: 144-184.

Vymazan, J. (1995): Algae and Element Cycling in Wet Lands. Duke Univ. School of the environment. Duke Wet land Center Durham, North calorina. CRC Press. Inc.

Wong, P.T.S. and Dixon, D.G. (1995): Bio-assessment of water quality. Environmental Toxicology and Water Quality, 10: 9-17.

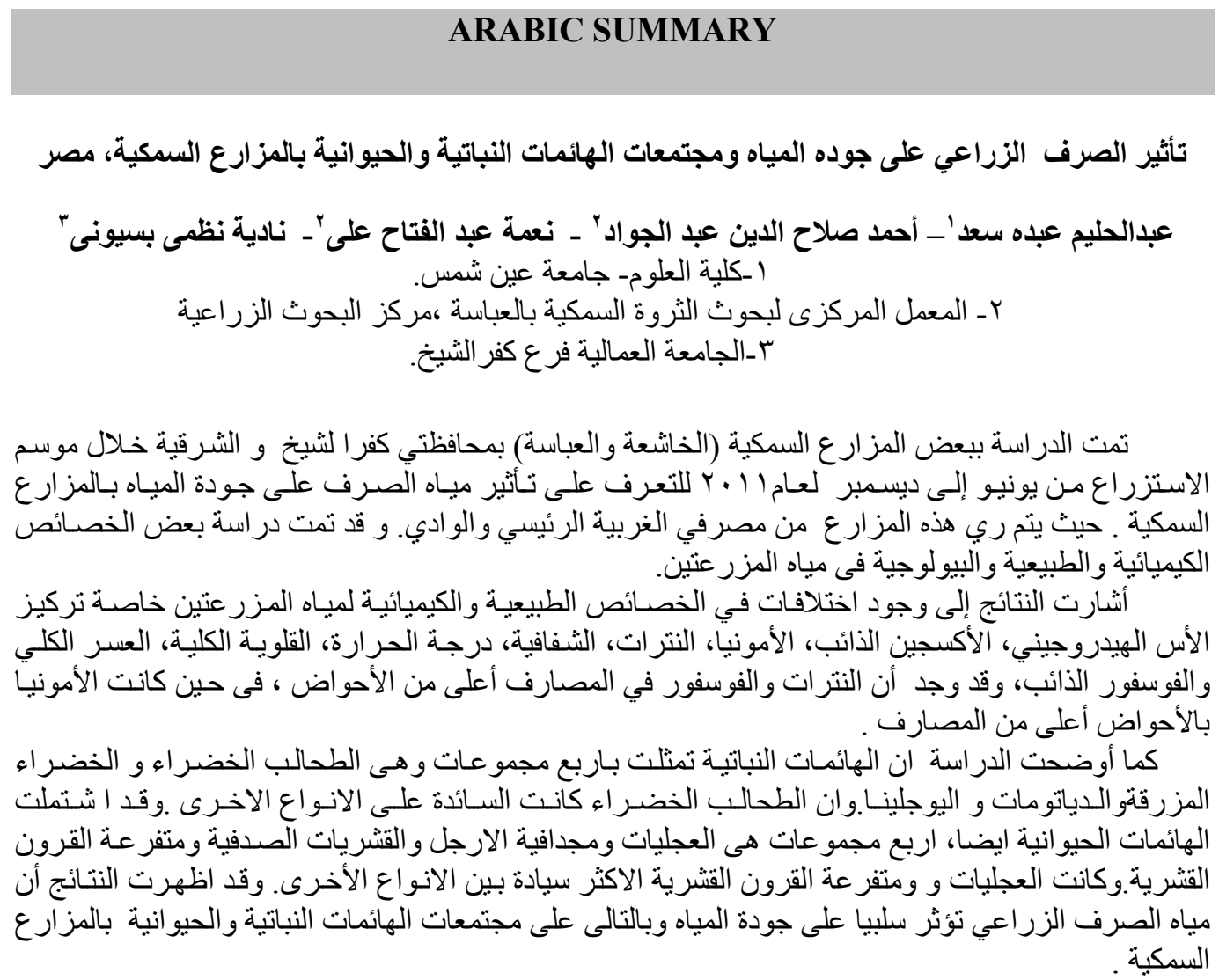

